DOI https://doi.org/10.18551/rjoas.2017-04.24

\title{
DETERMINANT OF BUSINESS DIVERSIFICATION OF HOUSEHOLD'S OIL PALM PLASMA SMALLHOLDERS IN BAHAR REGION, JAMBI PROVINCE, INDONESIA
}

\section{Rahman A.}

Department of Agribusiness, Faculty of Agriculture, University of Jambi, Indonesia

\author{
Zahri Imron, Husin Laila, Adriani Dessy
}

Department of Agribusiness, Faculty of Agriculture, University of Sriwijaya, Indonesia

\author{
*E-mail: abdur.jambee@yahoo.co.id
}

\begin{abstract}
This study aims to describe the efforts of the productive economy other than oil palm plantation business developed by smallholders under replanting risk, and analyze the effect of economic variables on the implementation of business diversification of household oil palm plasma smallholders. The study was conducted in the Bahar Utara, Sungai Bahar, and Bahar Selatan Sub-district respectively in Jambi to 200 respondents. Data were analyzed using Ordinary Least Square. The result showed that there are many alternatives to economically productive activities in addition to the farmer's main business oil palm plasma. To develop the business diversification in household smallholder oil palm plasma, the various stakeholders need to keep the increase in smallholding oil palm production continuously, continue to encourage capital investment, as well as reducing the available time leisure in the households of farmers by exploiting business opportunities by local resource that acceptable by both domestic and export markets.
\end{abstract}

\section{KEY WORDS}

Replanting, diversification, household, palm oil.

Diversification efforts in Indonesia are feasible by households because of the abundance and diversity of core business fields that people have done for a long time. From the data of National Social and Economic Survey (Susenas) 2015 may be seen that the main occupation of the population aged over 15 years show considerable variation in which 38.70 percent was as a worker/employee or employees, while only 4.65 per cent of workers in agriculture (Central Bureau of Statistics, 2016 ). Although only a minority of workers in agriculture, but in fact many types of productive business outside of agriculture in the countryside that can be done by the farmer and his family, not just on the farm (on-farm) but also outside the farm (off-farm) as trade and services, including agro-industry worker as an employee or perform household handicraft industry. Moreover, in a rural area that has developed into a new economic growth center.

The centers of economic growth in rural areas has been widely coincided with the development of plantations and palm oil processing industry of CPO (Crude Palm Oil) in rural areas. It is characterized by the development efforts of the production and services within both plantations that relate directly or indirectly to the palm oil industry. It can even be said to these efforts is supporting sector for the economic sustainability of the main sectors, namely oil palm industry. This is certainly an opportunity for the public or the farmers and their families to diversify its business in order to obtain alternative sources of income (income-generation).

Business diversification is becoming increasingly important in the growth cycle of oil palm trees that has entered a period of replanting as it is now, especially for the plant over the age of 25 years. According to the agriculture ministry plan based on existing Plantations Fund Management Body (BPDP), in 2016, approximately 63,000 ha of oil palm, particularly smallholders belonging that now must be replanted, but still tilled by farmers. Although palm 
oil is one of the plants chosen because they can improve the lives of farmers who originally is from the poor who do not have assets in agriculture, but in fact at the end of the crop cycle there are many farmers who are not able to perform replanting. One reason for the inability of farmers to rejuvenate the plasma is for failing to accumulate capital for future productivity. If this source of income for farm households over just relying on oil palm plasma, it is certain that the farmers will be difficult to replanted. In addition, their fears of losing revenue that only one of the oil palm plasma, although the value is very small, so therefore farmers do not adopt replanting.

Phenomenon in the field shows that not all farmers were not doing replanting caused by consumer behavior which is counter-productive, but rather by their productive activities out of plasma (diversification) so ignore replanting. There is a variety of investment activities that done farmers like to develop oil palm plantations outside the plasma, raising and opening the trading business as well as services and others. Visually there are many farmers who managed to improve their lives despite the plasma that are not productive were still harvested. This study examines the diversification efforts of farmers in one of the centers of palm oil production in Indonesia, Jambi Province. Introduction of oil palm in Jambi Province conducted in 1983/1984. Introductions palm oil is done in order to diversify sources of foreign exchange of crop plantation which was originally dominated by rubber smallholder. Plantation development is done through a Nucleus Estate Smallholders program (NESS) or Perkebunan Inti Rakyat (PIR) where the company in this regard PTP. Nusantara VI acts as a nucleus plantation owners and farmers participating in role as owners of plasma PIR around the nucleus (called plasma farmers) are the same breadth is 2 ha. Cultivation of plasma by farmers was coordinated and supervised by the core company within the framework of the technology transfer program in the cultivation of oil palm. Through the Program PIR oil palm is expected livelihoods of farmers in this area is increasing.

The purpose of this study was to 1) Describing the economic efforts of productive than the business of oil palm plasma were able to be developed by farmers under replanting risk; 2) To analyze the effect of economic and non-economic variables of the implementation of business diversification of household oil palm smallholders. In this study measured business diversification of the large difference in income from household business to income from plasma pure. Under conditions of farmers risk should be able to reduce the impact of the fall in oil palm production of plasma by doing productive activities outside of farming oil palm plasma.

\section{LITERATURE REVIEW}

Farm diversification is an attempt to diversify crops and/or livestock or other efforts by farmers in farming. This is an activity of farmers or households that are often found in agricultural areas in Indonesia, especially crop farming and horticulture. Farmers will allocate potential of labor and capital to the various business activities. The purpose of this farm diversification is to minimize the risk of loss in certain farm management can even maximize profits (Heady, 1952; Debertin, 1986; Luat, 2001; Battacharyya 2008 and Kanyua et al., 2013). Diversification efforts are usually carried out by low-income residents so it can be said that diversification is a survival strategy.

Luat (2001) states that diversification is a strategy shift of the plant that is not profitable to more profitable crops, from planting system and its variations, increase exports and competitiveness of the domestic and international markets, safeguarding the environment and create the best combination for Agriculture-Livestock-Forestry and Fisheries. In another sense diversification can also be defined as a shift in farming resources (on-farm resources) to non-farming activities (off-farm resources) or a mixture of both activities are complementary in agriculture (Battacharyya, 2008). Then Kanyua et al. (2013) define agricultural diversification as an effort to adjust the pattern of farming that aims to increase farmers' income, reduce income vulnerability and risk.

In general, researchers at the top to enter the variable area (size) of land, education, access to capital, access to transport, distance and market access, gender, cooperative 
membership, market experience, which is observed as the determinants of business diversification (Schwarze and Zeller, 2005; Kanyua et al., 2013; Bhattacharyya, 2008; Rehima et al., 2003 and Finocchio and Esposti, 2008). Meanwhile, Sichoongwe et al. (2014) included for the type of land management mechanism as a determining factor for the implementation of the diversification by farmers. In the economic well-being factors in health and education becomes the dependent variable (dependent variable). In this research spending on health and education will be the variable that will be tested the effect of the implementation of business diversification (independent variables) include in 'Capital household investment'. Acharya et al. (2011) measured the effect of variable income per capita, population urbanization, the area of high production, sharing areas of irrigation, rainfall, average land area, the number of markets per $1000 \mathrm{ha}$, the use of fertilizers $(\mathrm{kg} / \mathrm{ha})$, the length of road, \% ownership small business land and mechanization on the XS implementation level of diversification as measured using the Composite Index Entropy or CEI. Acharyya research results that in each group (group) different crop factors that determine the amount of its CEI index. Loison (2015) exposing classification for diversified livelihoods household by sector (non-agricultural farm), by function (wages-employee and wage own-business), and location (on-off farm). Loison find that diversification not yet benefitted the smallholders in rural, because of asset constraints.

As an effort to diversify sources of income, the diversification of activities can be a source of active and passive income. It really depends upon how farmers allocate capital and labor family for any such activities, whether in private or otherwise have to pay someone else. With a smaller capital investment, usually farmers will do their own business, but if a large-scale capital investment then he would not do himself. In fact, they only expect to benefit from capital invested in the form of shares or ownership papers gardens.

\section{METHODOLOGY OF RESEARCH}

The research sample area's is an area of palm oil plasma, called plasma PIR-Bun, in Bahar region, Muaro Jambi, Jambi Province, Indonesia, which is a pioneer in the introduction and development of oil palm plantations in this province since year 1983/1984. There are three sub-districts region sampled namely Sungai Bahar, Bahar Utara, and Bahar Selatan Subdistricts. The population of the whole research area of approximately 13.704 heads of households where 12.334 of them are smallholder oil palm land division project where 2 ha per household. Sampling of respondents was conducted using simple random sampling of 200 households. Interview method is used in the data collection for primary data by questionnaire list from smallholders. The secondary data collected by a recording of the government institution repor subdistrict.

This study describes the productive economic effort by households, farmers apart from the main business, namely oil palm nucleus estate plasma or plasma. There are two questions as a proposition of this research. The first proposition of this research is how the farmer's response if the productivity of plasma decreased. As described above, agronomically, the production of palm oil in the phase of replanting will continue to decline until it passes the threshold economical. Differences in farm management by farmers led to differences in the results even though over the same area. Therefore, the carrying capacity of the smallholding to the household economy will be different from one farmer to another farmer, depending on how farmers manage their farming. If the plasma is no longer able to meet all the needs of the household, then the farmers will naturally try to cover those needs with other business alternatives as anticipation. For those reasons, in general, farmers had planted yard area which was originally intended for farming crops to plant oil palm. For farmers who are able to accumulate capital, then seeking additional revenue from outside the plasma was applied, for example by buying the land around plasma or outside of plasma so as to increase the area of oil palm land. Besides, farmers can also capital invest in other productive ventures outside the oil palm plantations such as trading or breeding so far as not affecting the labor requirements for palm oil. If farmers are not capable of carrying out these alternatives and only relies on plasma, then the best way possible is the adjustment of 
consumption with farm income is frugality in spending. How to illustrate the extent to which the productive efforts that have been made by respondents as already stated in the first proposition of this study, is to use a descriptive analysis. The second proposition is whether the implementation of diversification was influenced by variables of economic and noneconomic, among others, production, consumption, labor, household investment, and counseling. The Counseling or information is very important to develop other farmer's business. It measured by ever or never got information on how to problem solved by combining the replanting and diversification from the government or company. In this study, it was assumed that the implementation of business diversification was identical with contributing revenue of outside the main business. While the economic variables include the production, consumption and the outpouring of labor and household capital investment. For noneconomic variables in this analysis using dummy variables coaching both by a government and by the core company of the implementation of the replanting combined with domestic business diversification. If the variable YINVL implementation is measured in IDR/year, then it can be formulated equation econometric relationship between YINVL with economic and noneconomic variables in multiple regression equations as following:

$$
\begin{aligned}
& \text { YINVL }=f(P R O D, K O N, \text { IVRT, JMTK, BINA }) \\
& \text { or } \\
& \text { YINVL }=b_{0}+b_{1} \text { PROD }+b_{2} \text { KON }+b_{3} \text { IVRT }+b_{4} J M T K+b_{5} \text { BINA +e } \\
& \text { Expected bi }>0 \text { where } i=1,2, . ., 5
\end{aligned}
$$

PROD variable is the production of fresh fruit bunches (FFB) measured in tons/year. KON variable is the amount of consumption expenditure of households consisting of food and non food expenditures are measured in IDR/year. IVRT variable is the household investment as measured by the sum of oil palm plantation investment (investment replanting), investment in education and health, investments are measured in IDR/year. BINA variable is a dummy variable to distinguish farmers who ever or never receive coaching from the core enterprise or government related with combination of replanting and diversification where BINA = 1 was ever, and BINA = 0 was never. Variable $e$ is the residue term that is expected to be zero and $b$ is parameters estimation that obtained trough Ordinary Least Squares (OLS).

To build an econometric multiple regression model with Ordinary Least Square, then the use of the basic assumptions of a regression model is very important. Power guess a model can be applied only if there is no violation of the assumptions in the preparation of the model. The basic assumption of a regression known as classical assumptions. A regression is built on the assumption that the data used normal spread, no interference multicollinearity, heteroscedasticity, and autocorrelation. Especially for the autocorrelation test was not performed because the data used is data shortly (cross-section). Therefore, the classical assumption used in this study is the normality, multicollinearity, and heteroscedasticity. The normality, multicollinearity, and heteroscedasticity test used the Jarque-Bera, BreuschGodfrey Serial Correlation LM Test and White test respectively. Based on the model results of the regression equation (2), the classical assumption test result, there is no symptomatic unnormally data, multicollinearity and heteroscedasticity.

\section{RESULTS AND DISCUSSION}

On average farmers currently have a plasma area over 2 ha, with the largest distribution area of 2.5 ha. For farmers, the right to make decisions when the plasmais still very productive, so the lack of income from plasma has now successfully closed by palm oil production outside the plasma that has been prepared long in advance. Data addition of palm plantation area in the most comprehensive study is 6 ha. But most farmers still has a land area of 2.5 ha. With the land area fixed (2 ha), while production of fresh fruit bunches the lower, the income of farmers will be lower so feared would be increasingly unable to meet his family's needs include for replanting. 
Replanting, in this terms is the plasma rejuvenation, is the action that is necessary to save the sustainability of plasma. In response to these conditions, the responses of farmers in carrying out replanting can be seen in Table 1. From Table 1 presented that no ones' respondent who did a total replanting of the plasma. Thus it is evident that the real farmers are still reluctant to lose income from the orchard plasma albeit slightly.

Table 1 - Replanting that Applied by Plasma's Smallholders in Study Area, 2016

\begin{tabular}{lll}
\hline Replanting Methods & Amount of Respondent & $\%$ \\
\hline Inserts in plasma & 17 & 8,5 \\
Inserts in plasma and new land & 14 & 7 \\
In yard & 28 & 14 \\
In yard and new land & 96 & 48 \\
Inserts in plasma and courtyard & 45 & 22,5 \\
\hline Amount & 200 & 100 \\
\hline
\end{tabular}

Diversification Response of Respondent. Diversification is the selection of productive activities undertaken by the respondent to offset the fall in income from plasma that under replanting risk. To look at the matter, Table 2 illustrates the farmer's response to the condition of plasma through venture outside plasma. There were four main group of business diversification that farmer done. There are four main group of business diversification that farmer done. Labour plantation is the dominant choosing economic activities of the respondent so followed by trading activities.

Household income contribution from outside of smallholdings occupies more than 50 percent of the total income, is an evidence of the role of diversification effort beyond of oil palm plasma income. It is very important for maintaining continuity economic of farmers households and smallholdings.

Table 2 - Implementation of Business Diversification of Household outside Oil Palm Plasma in the Research Area, 2016

\begin{tabular}{lllll}
\hline № & \multicolumn{1}{c}{ Business Name } & $\begin{array}{c}\text { Number of } \\
\text { respondents }\end{array}$ & $\%$ of respondent & $\begin{array}{c}\text { Average income } \\
\text { contribution (IDR/year) }\end{array}$ \\
\hline A & Non Oil Palm business & & 15,5 & 5.739 .600 \\
& Livestock / Fisheries & 31 & 38,5 & 13.611 .600 \\
& Labour plantation & 77 & 6,0 & 17.236 .800 \\
& Service Business & 12 & 25,5 & 15.918 .000 \\
& Trading & 51 & 85,5 & 13.126 .500 \\
& Average & 171 & 100 & 18.319 .180 \\
B & Oil Palm Farming Outside Plasma & & $31.445,680$ \\
C $\quad$ Total income of Outside Plasma (A+B) & & & $30.152,630$ \\
D & 200 & & \\
\hline
\end{tabular}

Determinant Factors of Diversification Business of Plasma Household. How economic and non-economic factors affected the household income diversification were presented in equation (2). The regression analysis the effect of economic variables (total palm oil production, consumption, and investments) and non-economic variables such as coaching or counseling on matters related to the problem one thing replanting and diversification efforts by the government or the company's core, can be seen in Table 3.

Table 3 - Regression analysis of economic and non-economic factors that affect the implementation of household business diversification

\begin{tabular}{lllll}
\hline Variable & Coefficient & Std. Error & t-Statistic & Prob. \\
\hline C & -22781.39 & 3753.848 & -6.068809 & 0.0000 \\
PROD & $\left.7512.310^{* *}\right)$ & 635.3617 & 11.82367 & 0.0000 \\
KON & -0.631840 & 1.299083 & -0.486374 & 0.6273 \\
IVRT & $\left.0.043256^{*}\right)$ & 0.022032 & 1.963351 & 0.0510 \\
JMTK & $\left.135.2351^{* *}\right)$ & 23.04255 & 5.868930 & 0.0000 \\
BINA & 2099.358 & 1621.657 & 1.294576 & 0.1970 \\
\hline
\end{tabular}

Dependent Variable: INVL; $R^{2}=0,83 ; A d j-R^{2}=0,82 ;$ F-stat. $\left.=189.59 ;{ }^{*}\right)$ significant ; ${ }^{* *}$ ) high significant. 
From the regression results in Table 3 , it is known that the $R^{2}$ value of 0.83 indicating that the ability of independent variables affects the dependent variable changes by 83 percent, the remaining 17 percent is explained by other variables outside the model. Different test overall ( $F$ - test) indicate that jointly affect the independent variable on the dependent variable are significant at $\alpha=0.05$. However, in the partial test, there is two independent variables that did not affect the dependent variable, ie consumption (KON) and guidance by a government (BINA), while variable PROD, IVRT, and JMTK are the very significant effect. PROD variables influence the YINVL very significant at test level $\alpha=0.01$. The regression coefficient is 7512.31 indicates the magnitude of change marginal diversification of revenue due to the increase the total palm oil production unit (in tons). Increased production can occur in plasma are still productive and orchard development outside the plasma due to the age of planting the relatively younger. Thus, the higher the production of oil palm plantations outside the plasma will be the higher the income of the household business diversification.

Variable consumption (KON) did not significantly affect the implementation of business diversification, but the regression coefficient is negative indicates a trend away from diversified activities with increasing household consumption. This is understandable because theoretically if consumption is increased then the activities of saving hard to do so that farmers cannot do business development. Not influential variables diversification of consumption to households has the following arguments. If we look at the magnitude of the average consumption in the research area of IDR 1.666 million per month or a total monthly expenditure including non-food IDR 2,263.900 with an average dependents 3 person, then the average net income of IDR 4,039.316 per 3 hectare or per household actually means farmers can make an investment for their savings in expenditure. In this case, farmers can still increase their consumption without affecting activities of diversification, because it is still able to pay the loan if the business capital investment.

\section{CONCLUSION AND SUGGESTIONS}

This study found that the livelihood activity of the farmer's households in the research areas had been not completely dependent on the oil palm plasma but from the business of the other too. Farmers will diversify household economy in line with the decline in FFB products from plasma. These can be grouped into two groups ie as wage laborers and the self-employed. In the group activities of laborers, most farmers choose as laborers at the community and core company land. In the group of self-employed, farmers perform various business activities include oil palm cultivation in plasma, livestock, fisheries, trade, and services.

In order to the empowerment of farmers or planters, either individually or institutionally, the government has to focus on the problem of providing cheap funds, not only for replanting, but for other businesses too. Assistance or counseling would be better if not only focus on the implementation of the standards replanting of the plantation, but also directed at potential exploration and training for farmers to diversify the business forward in the longterm economics of household farmers no longer simply rely on plasma only.

\section{ACKNOWLEDGEMENTS}

In particular we would like to thank the Directorate General of Higher Education Ministry of Research and Higher Education that has funded this study and also to the team of enumerators this study is Riswanto and Reci Pebria Wahyudi, respectively the student final level S1 courses Agribusiness, Faculty of Agriculture, University of Jambi and Munawar, Alumni Diploma III Agribusiness, Faculty of Agriculture, University of Jambi. 


\section{REFERENCES}

1. Acharya, S.P, Basavaaraja, H.,Kunal, L.B.,Mahajanashetti,S.B., and Bhat, A.R.S. 2011. Crop Diversification in Karnataka: An Econmic Analysis. Agricultural Economics Research Review, Vol.24 Juli-Decembar 2011. 351-357

2. Badan Pusat Statistik. 2014. Statistik Indonesia 2014.

3. Barnum, H. N. and L. Squir.1979. An Econometric Application of the Theory of the FarmHousehold. Journal of Development Economics 6 (1979) pp. 79-102. North Holland Publishing.

4. Battacharyya, R., 2008. Crop Diversification: A Search for an Alternative Income of the Farmers in the State of West Bengal in India. International Conference on Applied Economics - ICOAE.p. 83-94

5. Becker, G.S.1965. A Theory of the Allocation of Time. The Economic Journal. Vol. 75 no 299. Pp. 493-517

6. Culas, R., and R. Mahendrarajah.2005. Causes of Diversification in Agriculture over Time: Evidence from Norwegian Farming Sector. Paper prepared for precentation at the $11^{\text {th }}$ Congress of the EAAE. The Future of Rural Europe in the Global Agri-Food System. Copenhagen, Denmark. August 24-27.pp. 351-357

7. Debertin, D.L.1986. Agricultural Production Economics. Macmillan Publishing Company, New York, USA.

8. Heady.E. 1952. Diversification in Resource Allocation and Minimization of Income Variability. Journal of Farm Economics. 34:482-496

9. Kanyua, M.J. et al. 2013. Factor Influencing Diversification an Intensification of Horticultural Production by Smallholder Tea Farmer in Gataga District Kenya. Current Research Journal of Social Sciences 5(4): 103-111

10. Loison, A.S. 2015. Rural Livelihood Diversification in Sub-Saharan Africa. The Journal of Development Studies. http://dx.doi.org/10.1080/00220388.2015.1046445

11. Luat, N.V.2001. Crop diversification in Vietnam.FAO Document Repository. Regional Office of Asia and Fasific. Bangkok Thailand.147-155.

12. Uma, K.U, et al. 2014. An Investigation of the Effect of Investment and Saving in Nigeria Economy. Proceeding of Sosioin14-Inernational Conference on Social Science an Humanities, 8-10 September 2014. Istanbul, Turkey. ISBN: 978-605-64453-1-6 